\title{
PENYEBARLUASAN IDE PEMBAHARUAN MELALUI PROGRAM DAKWAH KOMUNITAS
}

\author{
AHMAD MISBAHUL ANAM \\ misbahulanam@stidnatsir.ac.id \\ Program Studi Komunikasi Penyiaran Islam \\ Sekolah Tinggi Ilmu Da'wah Mohammad Natsir
}

\begin{abstract}
The buman is part of civilization that will be active, especially connected with the idea or value will be basis of their life. Defution of new idea is one of modern people's indicator. Comunity of moeslem's study is a small group discussion in structure of moeslem society should get establishment to make their idea reform be usefull. This group research is conducted to measure how they response value of reform. The result of this research is respondent have high awarness for idea of reform. It be indicated by respondent's answer wherever they said, "No".
\end{abstract}

Kata Kunci : Defution, reform, commity, process, and response

\begin{abstract}
ABSTRAK
Manusia adalah bagian dari peradaban yang akan aktif, terutama yang terkait dengan gagasan atau nilai akan menjadi dasar kehidupan mereka. Pengrusakan gagasan baru adalah salah satu indikator orang modern. Komunitas studi moeslem adalah diskusi kelompok kecil dalam struktur masyarakat moeslem harus mendapatkan pendirian untuk membuat reformasi ide mereka menjadi berguna. Penelitian kelompok ini dilakukan untuk mengukur bagaimana mereka menanggapi nilai reformasi. Hasil dari penelitian ini adalah responden memiliki kesadaran yang tinggi terhadap gagasan reformasi. Ini ditunjukkan oleh jawaban responden di mana pun mereka berkata, "Tidak".
\end{abstract}

Kata Kunci: Difusi, reformasi, komunitas, proses, dan respon

\section{PENDAHULUAN}

Saling mempengaruhi, menjadi satu kenyataan yang tak mungkin dihentikan, karena manusia dan kehidupanya selalu mengalami perubahan yang dinamis sebagai wujud dari taqdir ${ }^{1}$ Rabbaniyah. Dalam proses mempengaruhi, gesekan ide dan nilai tidak saja berproses sebagai suatu yang alamiah tapi juga didesain secara sengaja sebagai bagian dari entitas hegemoni dunia. Rogers dan Shomaker menyimpulkan bahwa tonggak perubahan sosial adalah komunikasi

${ }^{1}$ QS. Ali Imran : 11

39|Jurnal Dakwah | Vol.1 No.2 |2018 
yang intensif ${ }^{2}$. Artinya, komunikasi adalah sarana penyebaran yang paling efektif, komunikasi dengan makna yang seluas-luasnya.

Wujud dari proses kedinamisan manusia terungkap melalui pembaharuan yang tidak lagi sebuah ide yang kosong. Tetapi sudah berjalan mengikuti sejarah perkembangan manusia serta interaksi yang tidak lagi berjalan linier. Perkembangan dan kemudahan koneksi informasi tak terbatas menjadikan setiap entitas yang ber-nyawa, hasil industri dan ide-ide manusia berkolaborasi sesuai keperluan.

Bagi Islam dan umatnya, komunikasi tentu memiliki maksud lain dari sekedar terjadinya koneksi dan kolaborasi ini bagi kehidupan. Nilai-nilai Islam dijadikan pedoman bagi keseluruhan hubungan tersebut karena adanya tujuan yang diinginkan, yaitu kemuliaan manusia itu sendiri. Pesan Islam menyebutkan, “... wahai bangsaku, ikutilah para Rasul! ...”3. Islam menegaskan bahwa proses manusia haruslah mengikuti petunjuk, perubahan yang terjadi tidak boleh dibiarkan dan dibebaskan mengikuti kemauan manusia semata. Komunikasi adalah sarana penyampai pesan yang baik-baik, walaupun dengan proses yang boleh jadi njlimet dan membosankan.

Kemauan manusia sebagai wujud kemerdekaan berfikir, harus dibimbing dan dikoneksikan dengan kemauan Allah sebagai penjamin keselamatan dan kepastian langkah manusia menuju cita-cita panjangnya. Kebebasan ide manusia yang tidak dibimbing oleh ayat-ayat Allah, hanya membuat manusia berjalan menunuju ketidak-seimbangan hidup. Karena, setiap entitas kehidupan adalah rahasia yang tidak mungkin dipecahkan hanya karena kecanggihan skill manusia sendiri. Banyak rahasia yang tidak diketahuai dan difahami manusia terhadap kehidupanya sendiri.

Nilai-nilai yang berkembang di masyarakat ternyata banyak yang tidak memiliki kaitan dengan nilai-nilai Islam. Namun, karena perubahan masyarakat adalah suatu keniscayaan, dimana didalamnya mengandung pembaharuan, membuat manusia memasukkan ide-ide yang dianggap baru sebagai tuntutan kedinamisan hidup. Bahkan, untuk semua bidang kehidupan ide pembaharuan tidak lagi dapat dihentikan. Alasan ini seiring dengan potensi dasar manusia akan lahirnya inovasi-inovasi baru sebagai fenomena kehidupan serta eksistensinya.

Namun, bagi sebagian masyarakat kita akan menemukan fenomena sebaliknya terhadap ide pembeharuan ini. Bahkan mereka ada yang sudah "terlanjur" menutup diri terhadap ide baru yang dianggap menggantikan nilainilai lokal yang dianggap sudah selesai berproses dibandingkan nilai agama yang diyakininya. Ada gejala yang tidak konsisten antara berpegang kepada nilai agama

\footnotetext{
${ }^{2}$ Everett M Rogers dan F. Floyd Shoemaker, Mamasyarakatkan Ide-Ide Baru, Usaha Nasional Surabaya, 1987, cet IV, hlm. iv

${ }^{3}$ QS. Yasin : 20
} 
yang diyakininya dengan kultur budayanya. Satu sisi mereka menyatakan pada ajaran agama, tapi pada waktu yang lain, bahkan secara bersamaan dan bergantian, budaya lokal tersebut diyakini sebagai kebenaran mutlak. Sangat sulit untuk dilakukan semacam revisi kebenaran. Mayoritasumat Islam belum menyadari sepenuhnya, bagaimana mereka seharusnya ber-Islam dan menjalani kehidupan dengan nilai-nilai Islam secara murni.

Padahal Islam selalu berusaha untuk menyadarkan umatnya, bahwa tujuan pergerakan Islam adalah melahirkan di suatu tempat di dunia sebuah masyarakat yang seluruhnya commited kepada ajaran Islam dalam totalitasnya serta berusaha bernaung di bawah ajaran-ajaran itu dalam pemerintahan, politik, ekonomi, organisasi sosial, hubungan dengan negara-negara lain, pendidikan, nilai-nilai moral serta semua aspek lainya dari cara hidup ${ }^{4}$. Itulah cita-cita Islam dari dulu, kini dan akan datang tak pernah bisa dihentikan. Namun, karena masyarakat juga memiliki ide dan nilai-nilai psikologis dan kebanggaan atas identitas lokal, maka masih saja akan terjadinya kelahiran dan penguatan nilai-nilai lokal sebagai bentuk eksistensi identitas.

Terjadilah difusi (penyebar luasan) terhadap nilai-nilai tersebut dalam kehidupan masyarakat. Dalam bahasa Islam, difusi memiliki kesamaan makna dengan tujuan da'wah yang tidak saja menyebarkan tapi juga membina sehingga terjadi proses perubahan dari sebelumnya. Dalam peradaban Islam, proses perubahan itu melekat dalam pergerakan manusia yang memang secara fitrah dan secara syar'iyyah adalah suatu kebutuhan hidup dan tuntutan agama. Entah, seberapa besar dan dalam bentuk yang berbagai-bagai, yang jelas perubahan adalah suatu keniscayaan hidup manusia bahkan makhluk ini sendiri.

Akhirnya, nilai-nilai agama yang murni masih akan memerlukan waktu yang lebih lama lagi untuk berproses, berinteraksi dan saling membuat pengkodean sebagai bagian dari tuntutan terjadinya pembaharuan. Maka, dalam penelitian ini peneliti coba melakukan peng-katagorian nilai-nilai yang berkaitan dengan budaya lokal. Bagaimana respon masyarakat terhadap nilai-nilai yang memiliki unsur pembaharuan. Dimana yang dimaksud Da'wah Komunitas yang dilakukan Mahasiswi STID M. Natsir di beberapa komunitas Majlis Ta'lim ibuibu Cipayung Jakarta Timur. Pembaharuan disini adalah nilai-nilai yang akan terus diperjuangkan oleh umat beragama sebagai bagian dari gerakan pemurnian ajaran (tajdid) dan tanggung-jawab aktualisasi diri.

Dalam penyebarluasan pembaharuan ini, peneliti akan coba mengkonfirmasi nilai-nilai yang dianggap baru oleh jama'ah pengajian, apakah mereka setuju, tidak setuju dan tidak tau.Untuk hal tersebut penelitian ini dibuat dengan judul : Penyebarluasan Ide Pembaharuan Melalui Program Dakwah Komunitas ; Studi Mahasiswa STID Muhammad Natsir di Cipayung Jakarta

${ }^{4} J a ' f a r$ Syaikh Idris, Proses Islamisasi : Tantangan dan harapan, dalam Islam dan Pergerakan, Minaret kerjasama dengan PT. Amalmas Aji, th 1988, hlm. 117 
Timur. Pertanyaan yang diajukan kepada mereka meliputi beberapa aspek terkait tema ideologi, ibadah, pendidikan dan tren global. Pertanyaan dan jawaban sudah disiapkan dan akan dibahas pada halaman berikutnya.

\section{Proses Penyebaran Ide}

Penyebaran atau defusi sebenarnya adalah suatu aktifitas yang terjadi bagi kehidupan ini. Peradaban Islam menggunakan istilah "lita'aarafuu" saling mengenal-lah. Bentuknya kalimat aktif, antar dua personal yang menggambarkan tentang kedinamisan interaksi antar dua (minimal) personal. Islam dengan nilainilai universalnya telah sukses mendinamiskan dunia, walau seringkali dikesankan kurang baik. Tapi memng begitulah, suatu nilai akan direspon dengan proses yang berbeda-beda. Dalam proses tersebut, sangat dipengaruhi oleh kondisi individu, bagaimana cara berfikir dan apa saja nilai yang sudah inheren dalam benaknya. Masyarakat dimana mereka tinggal juga menyumbang terhadap proses tersebut, sampai mereka memutuskan untuk menerima atau menolak, bahkan mereka memerlukan waktu untuk benar-benar menolak dan mungkin juga pada akhirnya harus menerima.

Yang dimaksud dengan pembaharuan pada penelitian ini adalah inovasi dalam penelitian sosial. Inovasi adalah gagasan, tindakan atau barang yang dianggap baru oleh seseorang. Tidak menjadi soal, sejauh dihubungkan dengan tingkah laku manusia, apakah ide itu benar-benar baru atau tidak jika idukur dengan selang waktu sejak digunakannya atau diketemukannya pertama kali. Kebaruan itu diukur secara subyektif, menurut pandangan individu yang menagkapnya. Jika sesuatu ide dianggap baru oleh seseorang maka ia adalah inovasi bagi orang itu. Baru dalam ide yang inovatif tidak berarti harus baru sama sekali. Suatu inovasi mungkin telah lama diketahui oleh seseorang beberapa waktu yang lalu, tetapi ia belum mengembangkan sikap suka atau tidak suka terhadapnya, apakah ia menerima atau menolaknya ${ }^{5}$.

Setiap inovasi yang berproses, maka dapat dikenali melalui komponen ide yang ditawarkan, sampai-lah inovasi tersebut tidak memiliki wujud fisik, misalnya ideologi. Komunikasi manusia akan memindahkan ide inovasi tersebut bermula hanya sebatas sebagai sebuah informasi. Dari sebuah informasi yang boleh jadi tidak dipandang perlu, karena interaksi dalam komunikasi tersebut berjalan terusmenerus maka lampat laun, terjadilah proses keingin tahuan yang mendalam. Komunikasi yang awalnya hanya satu arah, kemudian berubah menjadi dua arah bahkan lambat-laun karena keingin tahuan yang semakin besar, maka komunikasi itu menjadi lebih intensif dan tidak lagi menggunakan dua jalur. Keingin tahuan

${ }^{5}$ Everett M. Rogers dan F. Floyd Shoemaker, Memasyarakatkan Ide-ide Baru, terjemah Abdillah Hanafi, Usaha Nasional Surabaya, 1987, cet-IV, hlm. 26 
menjadi lebih intensif dengan berbagai saluran yang adaKeingin tahuan menjadi lebih intensif dengan berbagai saluran yang ada.

Proses perubahan dengan ide baru akan semakin kuat, manakala ditemukan bahwa inovasi adalah sebuah kebutuhan yang didorong tidak saja pada aspek kemanusiaan, tapi sudah sampai pada keperluan keyakinan manusia. Pergerakan yang sponsori oleh keyakinan, akan menentukan tingkat proses yang lebih rumit, karena ia melibatkan pertimbangan pemahaman atas hakekat keyakinan tersebut. Sifat-sifat dasar yang diperlukan dalam proses ini dapat digambarkan seperti ; kedalam ilmu, kecakapan terhadap fenomena, pengalaman interaksi, keterlibatan langsung, serta kematangan berfikir sebaagai sarana menimbang apakah sebuah kebaruan diterima atau ditolak.

Yang jelas, sampailah kesimpulanya adalah penolakan, sebenarnya penolakan tersebut adalah wujud lain dinamisnya proses yang terjadi. Karena semakin ditolak sebuah ide, proses diskusi diseputar persoalan tersebut sedang berjalan sebagai pertanda bahwa ide yang ditolak telah bekerja sebagaimana mestinya. Diskusi menjadi hidup, ruang memilih menjadi luas dan kesempatan berfikir telah berhasil mengubah pola pikir masyarakat, karena perubahan adalah komponen abadi makhluk hidup di kolong langit ini.

\section{Ide-ide Yang Berkembang di Jama'ah}

Nilai-nilai yang coba digali dari jama'ah pengajian dari masing-masing kelompok dibagi menjadi bebarapa bagian yaitu menyangkut aspek teologi, aspek ibadah, aspek akhlak dan gaya hidup. Aspek teologi berkenaan dengan pertanyaan, "Bagaimana berobat ke dukun". Aspek ibadah berkenaan dengan pertanyaan, "Bagaimana pendapat Anda terkait bunga bank". Aspek pendidikan berkenaan dengan pertanyaan, "Bagaimana pendapat Anda tentang larangan murid berpacaran". Aspek gaya hidup, berkenaan dengan pertanyaan, "Bagaimana pendapat Anda tentang makan dan minum dengan menggunakan kanan kirl".

Pertanyaan-pertanyaan diatas, direspon oleh jama'ah dengan cara memilih jawaban yang sudah ditentukan yaitu ; boleh, tidak boleh dan tidak tau. Penentuan jawaban ini untuk memudahkan dalam pertanyaan ke responden melalui relawan pengisian oleh para mahasiswi. Peneliti ingin mengetahui bagaimana jama'ah pengajian menyikapi hal-hal tersebut walaupun dengan cara memilihkan jawabannya. Hal-hal tersebut sebenarnya sudah lama menjadi bagian dari kehidupan masyarakat. Selain itu, setiap pertanyaan adalah ringkasan materi yang selama ini disampaikan oleh mahasiswi dalam rangka pembinaan dan perkenalan terhadap nilai-nilia Islam. Penelitian ini ingin mengetahui respon mereka terhadap beberapa nilai yang ditawarkan mahasiswi, dengan alat ukur berupa jawaban "Boleh", "Tidak" dan "Tidak tahu”. 


\section{METODE PENELITIAN}

Sampling klaster, yaitu proses pengambilan sampel dengan memilih kelompok, bukan individu secara acak. Seluruh grup atau kelompok pada suatu populasi memiliki kesempatan dan kemungkinan yang sama untuk diseleksi menjadi sampel. Bentuk sampling ini dilakukan, terutama apabila tidak ada kerangka sampling ${ }^{6}$. Cara ini dipakai untuk mempermudah dalam pengamatan dan mengenali kelompok-kelompok yang boleh jadi tersebar diberbagai tempat.

Dalam penelitian ini, peneliti memanfaatkan Majlis Taklim dibeberapa tempat, dimana mahasiswi STID M. Nastisr sedang melakukan Pengabdian Lapangan selama 4 semester. Pengabdian tersebut populer dengan nama Komunitas Pecinta Majlis Taklim, dimana pelaku dan pesertanya adalah kaum wanita. Data yang dihimpun adalah bagaimana sikap mereka terhadap nilai-nilai agama yang selama ini cenderung dianggap biasa dengan alat bantu berupa pertanyaan dan jawaban sederhana : boleh, tidak boleh, dan dan tidak tau. Jawaban dibuat untuk menyederhanakan proses penggalian dan untuk memberikan rasa nyaman kepada para peserta pengajian agar tidak merasa digurui dan tertekan, jika ditanya-tanya. Banyak diantara mereka tabu dengan pertanyaan. Ketabuan tersebut ditandai dengan rasa canggung dan tidak nyamannya beberapa orang terhadap suatu pertanyaan yang menyangkut nilai atau simbul-simbul dari ajaran agamanya.

\section{HASIL PENELITIAN DAN DISKUSI}

Salah satu aspek penting dari proses pengembangan masyarakat adalah bahwa proses tersebut tidak dapat dipaksakan ${ }^{7}$. Pemaksaan membuat kondisi dimana seseorang akan kehilangan kemerdekaan dan aktifitas berfikir. Pertimbangan yang seharusnya hadir dalam penentuan pilihan menjadi kurang mendapatkan porsi yang adil. Akal manusia menjadi sehat dan mengeluarkan fungsi yang banyak jika dilibatkan dalam proses menjadi. Macetnya proses menjadi, seringkali karena ada semacam kultur manusia yang hilang, padahal kultur adalah bentuk eksistensi berfungsinya daya pikir manusia.

Aspek pertama yang ditanyakan kepada jamaah adalah pada wilayah teologi berkenaan dengan pertanyaan, "Bagaimana berobat ke dukun". Pertanyaan ini diajukan karena masih banyaknya parktek-praktek perdukunan yang dijadilan sarana dalam menyelesaikan kesulitan-kesulitan hidup manusia. Cukup beragam jawaban yang mereka berikan, tentu karena jawaban yang

\footnotetext{
${ }^{6}$ Asep Saeful Muhtadi dan Agus Ahmad Safei, Metode Penelitian Da'wah, Pustaka Setia, Bandung, 2003, cet.1, hlm. 156

${ }^{7}$ Jim Ife dan Frangk Tesoriero, Community Development, Pustaka Pelajar, Yogyakarta, 2008, hlm. 356
} 
disedikan hanya 3 jawaban, menjadikan hasil penelitian ini belum dapat menggali informasi lebih jauh tentang alasan mereka memilih salah satunya. Tapi sederhana, peneliti menjadi tahu bagaimana mereka merespon pertanyaan diatas dengan jawabannya. Jawaban "Boleh" menindikasikan bahwa jamaah masih mentoleransi atau menerima perilaku tersebut. Boleh jadi mereka masih malakukan dan merasa masih memerlukan aktivitas tersebut. Cara tersebut menjadi paradoks dengan kehidupan ibukota yang serba rasional bagaimana cara berfikirnya. Ketidak rasionalan jamaah ditunjukkan dengan suatu pertimbangan tradisional berupa kecocokan berinteraksi dengan aktivitas irasional, yaitu para dukun yang perilakunya tidak dapat diukur dengan standar-satandar rasional.

Jawaban "Tidak boleh", menandakan adanya kecerdasan secara intelektual, berupa tata-cara dukun yang dipandang tidak rasional. Jawaban ini menjadi alat ukur, bahwa jamaah dapat menerima ide baru yang tidak sebagaimana pemahaman masyarakatnya. Sebenarnya menjadi lebih menarik, jika jawaban tersebut bisa dilanjutkan dengan pertanyaan-pertanyaan susulan agar dapat diketahui, apa sebenarnya alasan mereka sampai menyatakan "tidak boleh". Tapi cukuplah jawaban tersebut membantu bagaimana secara keseluruhan jamaah yang mengikuti pengajian mahasiswi, $90 \%$ sudah mengetahui larangan pergi ke dukun jika mereka mendapatkan kesulitan terutama saat mereka sedang sakit. Alternatif lain menjadi pilihan selain pergi ke dukun.

Hasil ini juga membantu program pemerintah, bagaimana cara menjaga kesehatan dan bagaimana seharusnya berobat. Satu pergeseran penerimaan yang mungkin berbeda pada kurun waktu 10 tahun yang lalu. Pembinaan mahasiswa ini secara intensif baru berjalan sekitar 4 tahun yang lalu di majlis ta'lim yang ada di daerah Cipayung-Ciracas Jakarta Timur. Tapi mungkin juga, "tidak boleh" disini bisa diartikan karena populasi dukun, tingkat kesulitan pergi ke dukun dan pilihan-pilihan berobat sudah semakin berkembang. Tapi kembali kepada tujuan pengabdian masyarakat yang dilakukan oleh mahasiswi, bahwa target tersebut sudah mampu menggeser bagaimana seharusnya mereka berobat dan tentu secara teologi telah menyelamatkan jama'ah dari perilaku menyimpang. Satu perilaku yang dalam teologi Islam dapat merusak amal, karena interaksinya dengan kesyirikan.

Aspek ibadah berkenaan dengan pertanyaan, "Bagaimana pendapat Anda terkait bunga bank". Pertanyaan ini lebih sulit dijawab oleh jamaah karena aspek ini tidak berdiri sendiri, namun bersandingan dengan kebutuhan dasar manusia secara langusng dengan ekonomi. Janji-janji bunga simpanan dari lembaga perbank-an kelihatanya masih menjadi satu pilihan utama bagi masyarakat. Mungkin juga karena pertumbunhan dan pelayanan bank yang non-ribawi belum sampai pada tingkat kelompok terkecil masyarakat, seperti pada wilayah kelurahan dan kecamatan. Pembukaan cabang-cabang baru bagi bank-bank 
ribawi jauh lebih masif dibandingkan bank non-ribawi. Pertanyaan ini soal bunga bank, masih secara merata terjadi antara yang boleh, tidak boleh dan tidak tau.

Hal ini mungkin juga terjadi karena belum banyaknya pembahasanpembahsan yang dilakukan mahasiswi terkait hal tersebut. Atau mungkin juga, masih belum dijadikanya bank non-ribawi sebagai sarana untuk mengelola keuangan secara Islami, selain memang diakui bank non-ribawi belum memberikan keuntungan secara ekonomi kepada para nasabahnya. Sementara jamaah pada umumnya, menempatkan lembaga bank hanya sebatas alat menyimpan dan transaksi ekonomi. Tapi, jika dilihat dari beberapa perubahan pemindahan jamaah untuk menggunakan bank non-ribawi dari bank-ribawi agaknya sudah terjadi proses pemahaman terhadap nilai manfaat yang tidak saja secara ekonomis, tapi lebih pada kepuasan bahwa apa yang dilakuak adalah bagaian dari ketaatan kepada Allah. Ketaatan secara ekonomi dalam pengelolaan keuangan, dengan prinsip-prinsip Islami.

Suatu kecenderungan ke arah perbaikan kwalitas ibadah, dalam bentuk pernyataan, 'apa manfaat bagiku'. Satu tren halal yang sudah menjadi bagian terpenting dalam kehidupan masyarakat Islam. Banyak komunitas Muslim yang hari ini lebih mementingkan aspek "Halal" dibandingkan sekedar murah, mudah, enak, nyaman dan untung. Pergeseran ke arah sebuah bernilainya aktifitas secara teologi ibadah. Banyak orang yang mulai menyadari arti penting nilai ibadah dalam segala aktivitas. Yuswohardi, mempetakan fenomena ini berkembang seiring lahirnya generasi Middle Class Muslim. Generasi baru yang lebih menekankan aspek rasionalis manfaat secara nilai agama ${ }^{8}$.

Aspek pendidikan berkenaan dengan pertanyaan, "Bagaimana pendapat Anda tentang larangan murid berpacaran”. Hubungan laki dan wanita adalah fitrah manusia sejak makhluk ini diciptakan. Kelas-kelas sosial, beda peradaban, terpisahnya benua dengan lautan serta faktor-faktor pembeda secara inderawi, tak mampu menghilangkan hubungan dua makhluk ini dalam kehidupan dimasyarakat. Kisah cinta du lawan jenis, bukan utopia kehidupan, tapi ia adalah nyata dalam setiap episodnya yang beraneka ragam. Seringkali sulit difahami, mengapa percintaan yang kelihatan seperti mimpi bisa terjadi.

Selama ini, hubungan laki-laki dan wanita ada pergeseran nilai. Hubungan tersebut dianggap biasa, bahkan kebiasaan tersebut menjurus ke arah nilai-nilai freesex. Hubungan yang tidak dijaga dengan nilai-nilai kemanusiaan bahkan lepas dari moral agama. Valentineday atau hari kasih sayang berubah menjadi hari freesex antar lawan jenis. Banyak orang tua yang juga menganggap bahwa kebebasan hubungan antara pria dan wanita, diajadikan semacam tes kematangan kedewasaan. Bahkan banyak orang tua yang resah, jika pemuda atau pemudi belum menemukan lawan bercinta. Fenomena interaksi wanita dan pria biasanya

${ }^{8}$ Yuswohadi, Middle Class Muslim, Gramedia, 2015, cet-2 
dimulai saat memasuki usia remaja, saat anak berada dibangku SLTP samapai dibangku kuliah.

Ada beberapa sekolah, terutama sekolah berbasis Islam menerapkan pemisahan antara kelas laki-laki dan perempuan. Tujuannya agar masing-masing siswa mampu mengendalikan diri dan terbiasa membatasi diri dalam membangun komunikasi lawan jenis. Karena banyak kasus-kasus pacaran kemudian menjerumuskan pada hubungan sek bebas, yang berakibat pada konsekwensi kejiwaan siswa. Kasus-kasus narkoba, merokok, tawuran seringkali diawali dari percintaan. Seorang lelaki, ingin dipandang hebat oleh lawan jenisnya jika dia mampu menunjukkan sifat-sifat kejantanannya melalui beberapa aktivitas tadi. Para orang tua yang rajin ngaji, dan telah merasakan bagaimana dampak pacaran para siswa, merasa setuju jika sekolah menerapkan pemisahan antara kelas-kelas laki dan perempuan. Namun kesulitanya adalah pada lembaga penyelenggara sekolah, karena regulasi tentang hal tersebut belum memiliki kekuatan hukum dan lembaga diberikan kebebasan dalam pelaksanaannya. Sekolah ataupun kampus, masing dipandang sebatas tempat belajar. Sekolah-sekolah atau lembaga Islam biasanya, lebih mampu menerapkan hal tersebut, karena anatar lembaga, orang tua dan anak-anak sudah relatif lebih care dalam memahmi aturan lembaga.

Namun demikian, pemisahan ini bukanlah suatu jaminan, ia hanyalah satu usaha untuk lebih menekan tingkat pergaulan bebas antar lawan jenis dalam komunitas sekolah. Tentu, juga akan berdampak saat masing-masing siswa sudah berada diluar sekolah. Jakarta, sebagai pusat pluralitas manusia tentu menjadi satu tantangan tersendiri dalam isu pemisahan siswa dan siswi. Tapi jika hal ini dapat difahami sebagai bagain dari pendidikan moral, tentunya bisa lebih mudah untuk diterapkan dengan tidak melanggar nilai-nilai kemanusiaan yang lain. Karena, tetap menjadi penting bahwa laki-laki harus kenal wanita dan demikian pula sebaliknya. Masing-masing tidak boleh hanya mengenal sejenisnya, karena nantinya akan berdampak pada hilangnya kehidupan, disaat yang laki-laki hanya kenal pada makhluk laki-laki saja. Sedang wanita juga hanya kenal terhadap wanita juga.

Keseimbangan hubungan ini harsulah tetap dirawat, karena dunia memerlukan hubungan yang halal antara pria dan wanita. Banyak kasus pacaran, ternyata tidak equivalen dengan hubungan pernikahan secara sah, tapi justru hubungan haram diluar pernikahan. Jika ini terjadi, wanita dan anak-anak akan menjadi korban. Jadi, pemisahan yang berkeadilan dalam kontek siswa adalah sarana mengelola komunikasi yang bertanggung jawab. Dari data penelitian yang penulis lakukan, kesadaran pemisahan ini belumlah dapat dirasakan secara lebih besar, karena fenomenanya barus sebatas ada pada komunitas-komunitas Muslim yang sudah melek syariat Islam serta memahami gejala-gejala sosial terutama terkait dengan kebebasan sek yang menjamur di masyarakat, khususnya anakanak muda. Untuk wilayah desa, kepatuhan pemisahan masih terasa kurang, 
karena baru ada, biasanya pada lembaga-lembaga pesantren. Tapi proses penerimaan terhadap larangan pacaran, sebenarnya memiliki keseiringan dengan problem-problem remaja pada suatu kawasan.

Aspek gaya hidup, berkenaan dengan pertanyaan, "Bagaimana pendapat Anda tentang makan dan minum dengan menggunakan kanan kiri". Berbagai latar masyarakat global, seperti film, fun, food dan musik adalah penyumbang terbesar perubahan terhadap gaya hidup manusia. Gaya hidup manusia akan semakin intensif manakala berkaitan langsung dengan hal-hal diatas, terutama sekali adalah soal makan dan minum. Nilai-nilai ketimuran dan ke-Islaman terlindas oleh fenomena gaya hidup hari ini. Tampilnya, public vigur yang muncul setiap acara yang disiarkan secara luas, telah mampu mengubah nilai-nilai Ketuhanan. Banyak orang yang mulai merasa nyaman dengan meniru tokohtokoh public, karena ingin dipandang sebagai sosok yang modern, sementara nilai dan moral agama adalah konservatif dan tidak kapable dalam menyeimbangkan perilaku manusia.

Mayoritas jawaban dari pertanyaan yang disebarkan, adalah memilih tidak boleh. Maksudnya mereka memiliki pilihan bahwa makan dengan berdiri dan dengan menggunakan tangan kiri adalah sesuatu yang tidak boleh dilakukan. Memang persoalanya, kita belum sampai mengetahui apa dasar mereka memilih tidak. Apakah tidak karena kesesuaian dengan adat ketimuran atau karena pemahaman agama yang diyakininya. Tapi jika kita kembali kepada proses pembinaan terhadap mereka oleh relawan da'wah, boleh jadi pilihan tersebut adalah karena kesadaran yang tumbuh selama mereka mengikuti pembinaan.

Kesadaran tumbuh seiring dengan proses pendampingan dan pembinaan. Tren-tren global sebenarnya bisa ditumbangkan dengan cara advokasi lokal yang intensif. Gerakan-gerakan da'wah yang diperuntukkan bagi pergeseran nilai negataif harus dikapitalisasi sampai pada obyek yang lebih kecil. Proses pendampingan face to face menjadi lebih ideal, karena hegemoni tren-tren global yang kuat. Hegemoni tersebut mencengkeram kesuluruahn potensi manusia dari aspek kejiwaan, hukum, politik dan ekonomi sekaligus. Secara kejiwaan masih banyak orang mengikuti tren untuk menaikkan rasa diri, lebih PD dan merasa sebagai orang modern. Ada kegalauan kelas sosial yang harus diatasi dengan cara mengikuti tren global.

Kondisi ini, sebenarnya menandakan kekacauan berfikir dan kerusakan mental yang serius. Kegiatan pembinaan adalah mengembalikan potensi jamaah ke nilai-nilai luhur warisan Rasulullah. Kesadaran mengubah tren global dengan nilai-nilai Islam secara langsung akan berkontribusi bagi perubahan perilaku masyarakat yang tidak sekedar baik, tapi juga mendorong kesadaran tumbuhnya nilai yang sebenarnya telah terbenam dalam hati mereka. Kesadran karena iman, tentu akan menggerakkan secara spontanitas tidak saja pada satu aspek perilkau makan, tapi juga hal-hal kecil dalam kehidupan ini. 


\section{KESIMPULAN DAN SARAN}

Beberapa aspek yang coba digali sebagai bahan untuk mengukur bagaimana penyebarluasn ide pembaharuan diterima, memberikan satu informasi penting bahwa, ide-ide pembaharuan akan diterima manakala disampaikan secara terus menerus. Minimal mereka mendapatkan satu kosa-kata baru tentang apa itu nilai. Nilai yang sebenarnya sudah mendapatkan dasar pisajakanya saat meeka menyatakan ke-Islaman. Aspek teologi mendapatka respon yang baik berupa jawaban "Tidak" maksunya tidak boleh dilakukan sebagai respon pertanyaan, "Bagaimana berobat ke dukun". Demikian juga pada aspek ibadah, pendidikan dan gaya hidup. Sebenarnya, masyarakat secara umum mereka menerima ide baru seiring dengan tingkat kematangan berfikir dan meningkatnya kesadaran terhadap nilai diri dalam setiap aktifitas.

Percepatan harus dilakukan lebih intensif untuk merawat penerimaan mereka terhadap ide-ide baru tersebut, dengan cara menggiatkan pembinaan. Nilai-nilai ini, juga dapat dimanfaatkan untuk menyadarkan kekeliruan pada nilainilai yang lain. Kampus harus lebih memberikan porsi yang maksimal, dari segi pembinaan kader-kader da'iyah yang akan diterjunkan, melalui pengayaan skil-skil khusus sehingga mampu membantu mereka dalam rangka meningkatkan kemampuan mengkomunikasi ide-ide yang lainya.

\section{DAFTAR PUSTAKA}

Al-Qur'an Al-Karim

Everett M Rogers dan F. Floyd Shoemaker, Mamasyarakatkan Ide-Ide Baru, Usaha Nasional Surabaya, 1987, cet IV

a'far Syaikh Idris, Proses Islamisasi : Tantangan dan harapan, dalam Islam dan Pergerakan, Minaret kerjasama dengan PT. Amalmas Aji, th 1988

Asep Saeful Muhtadi dan Agus Ahmad Safei, Metode Penelitian Da'wah, Pustaka Setia, Bandung, 2003, cet.1

Jim Ife dan Frangk Tesoriero, Community Development, Pustaka Pelajar, Yogyakarta, 2008

Yuswohadi, Middle Class Muslim, Gramedia, 2015, cet-2 